\title{
Police Role Big City of Semarang in Vigilantism (Eigenrechting) Prevention by Society
}

\author{
Donny Eko Listianto ${ }^{1}$ and Sri Endah Wahyuningsih ${ }^{2}$
}

\begin{abstract}
The violence that is rife today one of which is an act of vigilantism. Police as law enforcement officers play an important role in the response to vigilantism. Problems in this study were analyzed using role theory and the theory of criminal prevention. Semarang Polrestabes role in the response to vigilante violence committed by groups of people is to undertake pre-emptive, preventive and repressive. Preemptive effort is socialization and approach to society, while preventive measures are done by counseling or routine patrol. A repressive measure is a law enforcement efforts through a series of investigative actions until the submission of the dossier to the level of prosecution that the prosecutor's office. Internal obstacles that arise in the response to vigilante violence is the lack of personnel Satreksim, the concern experienced by police in law enforcement and the difficulty in calling witnesses. To overcome these obstacles with the addition of personnel and coordinate with the nearest police-police. The external resistance is distrust of the justice system, the spontaneous nature of the group of people who come from social pressure factors, the absence of mediator or parties who try to block such vigilante action. To overcome external obstacles to build partnerships with the community, especially the community leaders, religious leaders, youth leader, in the form of law sicialization dan another activities that can made the harmonization dan society understanding.

Keywords: Prevention; Vigilantism
\end{abstract}

\section{Introduction}

Law is a set of rules is coercive, which determine human behavior in society, which is made by a state official bodies and contain strict sanctions on those rules. ${ }^{3}$ Today, violence is rife one of them is an act of vigilantism. The act of vigilantism is not a stranger ears of the community. As an example of the tragedy that befell MA, a man who was beaten to death and burned by the residents for allegedly stealing an amplifier belonging to a Mushala in Bekasi. ${ }^{4}$

Judge himself had a close relationship with the illegitimacy of any criminal offense. Typically, with a criminal offense a loss. Sometimes the victim's own attempt to remove the injury he suffered by not wait for the action tools for countries such as

\footnotetext{
${ }^{1}$ Student of Master of Law, Universitas Islam Sultan Agung Semarang and Members of the Indonesian National Police (Polri), email: donnyeko20005@yahoo.co.id

${ }^{2}$ Lecturer of Faculty of Law UNISSULA Semarang

${ }^{3}$ Ishaq, 2012, Dasar-Dasar Ilmu Hukum, Jakarta: Sinar Grafika, p. 3.

4 Main Hakim Sendiri, nasib Tragis MA Korban Penghakiman Massa di Bekasi, (http://megapolitan.kompas.com, Accessed 24 April 2018).
} 
police or prosecutors, as if he judges himself. ${ }^{5}$ This phenomenon reflects the rule of law is no longer to be commander in social life cause adverse effects.

Courage people to take over the process of social control in the form of vigilantism, can be expressed as the fruit of a reform movement that has been bequeathed to the community, both positive and negative, such as freedom, courage, transparency of information, democracy and so on, which then grows "power" in society. Sense of power is then a driver of the emergence of vigilantism by society. ${ }^{6}$

Forms of vigilante action (Eigenrichting) one of them was beating and beatings carried out by the masses who can not control his emotions. Society tends to be brutal to those who are just suspected criminals and criminals were caught red-handed, the action taken this society is certainly not justified when viewed from the side of the law except for self-defense.

Several attempts have been made to try to uncover and dissect the issue of vigilantism. Police is a tool that plays a role in maintaining state security and public order, enforcing the law, and to provide protection, shelter and services to the community in the context of the maintenance of internal security. Indonesian National Police is the national police unity in carrying out the role as the keeper of security, keepers of public order, law enforcer and to provide protection and shelter and services to the public in order to maintaining security in the country.

Based on the above, the authors are interested in doing research by taking title "Police Role Big City Of Semarang In Vigilantism (Eigenrechting) Prevention By Society".

Based on the description of the background described above, then the problem is formulated as follows: 1) How Semarang Polrestabes role in the response to vigilantism (Eigenrechting) committed by groups of people?; 2) What barriers appears in the prevention of vigilantism in Semarang Polrestabes and how attempts to solve it?

\section{Research Methods}

This study is a socio-juridical. The data used are primary data and secondary data so that the data collection method is field studies and literature. ${ }^{7}$ The method of data analysis using qualitative analysis.

\section{Results and Discussion}

\subsection{Semarang Polrestabes Role in Vigilantism (Eigenrechting) Prevention By Society}

In order to vigilante violence prevention by Semarang Polrestabes making efforts that include preemptive action, preventive and curative. ${ }^{8}$

- Preemptive Action

Preemptive efforts in combating vigilantism conducted by Semarang Polrestabes is to appeal to the socialization to provide insight to the public about the security and

\footnotetext{
${ }^{5}$ Wirjono Prodjodikoro, 2012, Tindak-Tindak Pidana Tertentu Di Indonesia, Refika Aditama, Bandung, p.3

${ }^{6}$ Fitriati, "Perbuatan Main Hakim Sendiri Dalam Kajian Kriminologis Dan Sosiologis", MMH, Bd. 41 No. 2, April 2012, p. 162.

7 Ronny Hanitijo Soemitro, 1989, Metodologi Penelitian Hukum dan Jurimetri, Ghalia, Jakarta, p.9

${ }^{8}$ Results of interviews with prestige AKBP I.G.Adwi Perbawa Nugroho as operational unit of Semarang Polrestabes, Semarang, dated August 23, 2018.
} 
public order (internal security) and the law. Bhabinkamtibmas has an important role in the prevention of pre-emptive effort vigilantism, it is given the Bhabinkamtimas a police officer who was closest and direct contact.

- Preventive Measures

Semarang Polrestabes preventive efforts undertaken is done by a routine patrol by involving community leaders to prevent vigilantism, work honestly and transparently in order to increase public trust, providing legal counseling. preventive measures implemented by means of: ${ }^{9}$

- Build authority and legal certainty to satisfy the justice community.

- Appeals and legal counseling

It is expected that the public understands that the criminal judge to helplessness is an act contrary to the law and can be prosecuted. As executor of this activity is Bhabinkamtibmas in cooperation with community leaders, religious leaders and youth leaders.

- Carry out routine patrols.

One step prevents the occurrence of criminal acts is with regular patrols all over the place / area potential and prone to criminal acts in addition to their patrol expected the police to swiftly handle / securing the offender is caught by the residents not to become victims of vigilante by mass.

In efforts to combat acts of vigilantism backwardly a preemptive and preventive require contributions from the communities and community leaders. Contributions of community leaders be it religious, RT, RW, or the Village Head plays an important role in the response to vigilantism in the community. This is because the masses are more likely to listen to the call of community leaders from the call from the police. For that all community leaders should support each other and strengthen the performance of the police so that vigilantism can be anticipated and the period can be controlled.

- Repressive Measures

Repressive effort was made after the criminal act of vigilantism, this effort is the way in which the police if the means of prevention was considered a failure and vigilantism is still going on in the community. Efforts is investigative action against vigilantism. Usually the articles that have been violated in the act of vigilantism is Article 351 of the Criminal Code if the offender abused, Article 338 of the Criminal Code if the victim of vigilante die, if the perpetrators of violence against persons or items together would be subject to Article 170 of the Criminal Code, provisions the other is Article 406 of the Criminal Code if the offender destroys the victim's belongings that resulted could not wear such items.

Judging from the theory of crime prevention, efforts to combat domestic violence acts in accordance with the theory of crime prevention that says that the effort to overcome the evil done by means of pre-emptive, preventive and repressive action.

\footnotetext{
${ }^{9}$ Ibid.
} 
Pre-emptive and preventive action is non penal effort ${ }^{10}$ prevention vigilantism, while the repressive measures be classified in an effort penal investigation. ${ }^{11}$

Efforts to combat vigilantism by Semarang Polrestabes accordance role theory. This is as stated by Soerjono Soekanto which states that the role or the role of behavior patterns associated with status or status as a pattern of behavior. If a person is exercising its rights and obligations in accordance with the position then he runs a role. Police role in the prevention of vigilantism is expected roles (expected role), the role of which is carried out in accordance with the conditions set together. In this case Semarang Polrestabes do countermeasures vigilantism based on legislation including the Criminal Code, Act No. Act No. 2 of 2002 on the Indonesian National Police, and the Police Regulation No. 3 of 2015 on Community Policing.

In the case of mediation against vigilantism are role unadjusted (actual role) that is the role that is adjusted according to the situation or condition that is happening.

\subsection{Obstacles That Comes In Vigilantism (Eigenrechting) Prevention By Society In Semarang Polrestabes And Efforts to Overcome}

Efforts to combat vigilantism in Semarang Polrestabes there are obstacles to its implementation both from within and from outside. The internal barriers in the prevention of vigilantism such as: ${ }^{12}$

- Number of Criminal Police Unit of Limited Personnel

Law enforcement on cases of vigilante constrained because the number of police personnel are not proportional to the number of perpetrators of acts of vigilantism is usually done by the people (masses). It is the basis of a limiting factor law enforcement efforts in the police in cases of vigilante (Eigenrichting), due to the limited number of personnel dropped at the crime scene (the scene) is not proportional to the number of people there, it was that hamper the efforts of personnel police in the investigation effort. Then it will be difficult for the police in investigating further.

- The Concerns Experienced By Police Officers In Law Enforcement

The case of vigilante action (Eigenrichting) constrained because of their sense of concern on the part of the investigators, because this case involves the crowds. If the case is still followed by the police, it is feared will happen a huge protest by the people because of their family or community members who captured and detained by the police.

- Difficulty in calling witnesses

In terms of calling these witnesses many difficulties found by the investigating authorities, in addition to people who closed also because people do not coorperative and do not seem to want to give explanations even always cover any events act of vigilantism (Eigenrichting) which occur in their territory. In addition to

\footnotetext{
${ }^{10}$ Soedjono D, 1976, Penanggulangan Kejahatan (Crime Prevention), Alumni, Bandung, p.32

11 Barda Nawawi Arif, 2006, Masalah Penegakan Hukum dan Kebijakan Hukum Pidana dalam Penanggulangan Kejahatan, Bandung : Citra Aditya Bakti, p. 78.

12 Results of interviews with prestige AKBP I.G.Adwi Perbawa Nugroho as operational unit of Semarang Polrestabes, Semarang, dated August 23, 2018.
} 
people who do not want to give information, it is also done by the village head, the sub-district, and community leaders, they also seemed to be to protect and cover up the events that have occurred.

Efforts to overcome internal barriers is by adding personnel. The effort to overcome the obstacles in law enforcement in cases of vigilante action (Eigenrichting) is to coordinate with the nearest polices, as well as to motivate and equip police officers in carrying out their duties.

In addition to internal constraints, there are some external constraints in combating vigilantism. These barriers are: ${ }^{13}$

- Distrust of the justice system. Society and commensurate with what is done perpetrator.

- Their spontaneous nature of a society that comes from social pressure factor. Unemployment and difficult economic conditions make people become frustrated and did not think long. Vigilantism that is the "land" impingement of the mental pressure

- Society does not know how to report a crime. The absence of contact numbers of police are easily known to the public and also the distance between the scene with distant police station. This led the police came after criminals or suspected criminals is up beaten by mob.

- Absence mediator or parties who try to block such vigilante action. In an age of high-tech is actually a lot of busy people capture the moments vigilante with his cell phone, not to mediate.

As an attempt to overcome external barrier obstacle is the Police must build partnerships with the community, especially the community leaders, village chiefs, sir sub-district in the form of activities of legal counseling and other activities that may create familiarity and awareness of better law between police and the community. In addition, transactions are carried out legal education to the public associated with the act of vigilantism.

Judging from the theory of law enforcement, the obstacles arising in the fight against vigilantism in Semarang Polrestabes influenced by factors which include factors of law enforcement law enforcement officers, facility factors, community factors and cultural factors. ${ }^{14}$

\section{Closing}

\subsection{Conclution}

- Semarang Polrestabes role in the response to vigilantism (Eigenrechting) undertaken by community groups is to undertake pre-emptive, preventive and repressive. Preemptive efforts carried out by the unit Binmas with the dissemination and approach to society, while preventive measures are done by counseling or routine patrol. A repressive measure is an attempt law enforcement

\footnotetext{
13 Ibid.

${ }^{14}$ Soerjono Soekanto, 1986, Faktor-Faktor yang Mempengaruhi Penegakan Hukum, Jakarta: Rineka Cipta, p. 8
} 
through a series of investigative actions until the submission of the dossier to the level of prosecution that the prosecutor's office.

- The obstacles that arise in the prevention of vigilantism in Semarang Polrestabes comes from internal and external. Barriers internal of Satreksim number of personnel, the concern experienced by police officers in law enforcement and the difficulty in calling witnesses. To overcome these obstacles with the addition of personnel and coordinate with the nearest polices. The external resistance is in the form of public distrust of the justice system, the spontaneous nature of the group of people who come from social pressure factors, the absence of mediator or parties who try to block such vigilante action. To overcome external obstacles to build partnerships with the community, especially the community leaders, religious leaders, youth leader, in the form of law sicialization dan another activities that can made the harmonization dan society understanding.

\subsection{Suggestion}

- A need to increase partnerships with the community, especially the community leaders, religious leaders, youth leaders, to anticipate the occurrence of vigilantism.

- Needs to be disseminated to the public as well as legal counseling associated with vigilante actions on a regular basis.

\section{Bibliography}

[1] Barda Nawawi Arif, 2006, Masalah Penegakan Hukum dan Kebijakan Hukum Pidana dalam Penanggulangan Kejahatan, Bandung : Citra Aditya Bakti.

[2] Ishaq, 2012, Dasar-Dasar IImu Hukum, Jakarta : Sinar Grafika

[3] Wirjono Prodjodikoro, 2012, Tindak-Tindak Pidana Tertentu Di Indonesia, Refika Aditama, Bandung.

[4] Ronny Hanitijo Soemitro, 1989, Metodologi Penelitian Hukum dan Jurimetri, Ghalia, Jakarta.

[5] Soedjono D, 1976, Penanggulangan Kejahatan (Crime Prevention), Alumni, Bandung.

[6] Soerjono Soekanto, 1986, Faktor-Faktor yang Mempengaruhi Penegakan Hukum, Jakarta: Rineka Cipta.

[7] Constitution of the Republic of Indonesia of 1945

[8] Book of the Criminal Justice Act

[9] The Code of Criminal Procedure

[10] Act No. 2 of 2002 on the Indonesian National Police.

[11] Fitriati, "Perbuatan Main Hakim Sendiri Dalam Kajian Kriminologis Dan Sosiologis", MMH, Jilid 41 No. 2, April 2012.

[12] Main Hakim Sendiri, nasib Tragis MA Korban Penghakiman Massa di Bekasi, (http://megapolitan.kompas.com, accessed 24 April 2018). 